\title{
Annual variation of the malacofauna on two intertidal sandy substrates with rock fragments in southeastern Brazil
}

\author{
Marcia R. Denadai ${ }^{1,2}$; A. Cecília Z. Amaral ${ }^{1}$ \& Alexander Turra ${ }^{1,3}$ \\ 'Instituto de Biologia, UNICAMP \\ Departamento de Zoologia \\ (Caixa Postal 6109, 13.083-970, Campinas, SP, Brasil) \\ ${ }^{2}$ Pós-Graduação em Zoologia. marciard@hotmail.com (corresponding author) \\ ${ }^{3}$ Pós-Graduação em Ecologia. turra@unicamp.br
}

- Abstract: The temporal variation in molluscan communities was studied in two intertidal substrates composed of sand and rock fragments $(<300 \mathrm{~mm})$ in São Sebastião Channel, Brazil. Samples were taken between August 1995 and July 1996 in São Francisco (mainland) and Engenho d'Água (São Sebastião Island) beaches. A pronounced decrease in abundance and diversity of molluscs was associated with changes in the structure of the environment, caused by sea storms in the beginning of the summer (December), and by the increase of waste water discharge in this same period. Areas not subjected to such events showed no evident modifications in mollusc fauna structure during the sampling period, and the small oscillations observed were attributed to population recruitment. Both natural and human factors may be acting together in determining the community organization in these environments, as is also in typical sandy beaches.

- Resumo: Estudou-se a variação anual da comunidade de moluscos em dois ambientes entremarés constituídos por areia e fragmentos rochosos $(<300 \mathrm{~mm})$ no Canal de São Sebastião, Brasil. As amostras foram obtidas mensalmente entre agosto de 1995 e julho de 1996 nas praias São Francisco (continente) e Engenho d'Água (Ilha de São Sebastião). Uma marcante redução na abundância e diversidade foi associada às mudanças estruturais do ambiente, causada por ressacas do mar no início do verão (dezembro), e ao aumento no fluxo de esgotos domésticos neste período. Em áreas onde estes eventos não foram evidentes, não houve grande alteração na composição faunística, e as pequenas oscilações foram atribuídas ao recrutamento de populações numericamente importantes. Ambos os fatores naturais e antrópicos podem estar atuando em conjunto para determinar a organização da comunidade nestes ambientes, tal como ocorre em praias arenosas típicas.

- Descriptors: Molluscs, Annual variation, Environmental disturbances, Sandy substrates with rock fragments, São Sebastião Channel, Brazi1.

- Descritores: Moluscos, Variação anual, Distúrbios ambientais, Praias arenosas com fragmentos rochosos, Canal de São Sebastião, Brasil.

\section{Introduction}

Seasonal variation in marine communities is an actual topic of research. The importance of such studies lies in the fact that some temporal oscillations in diversity and community composition in coastal regions can be associated to human activities. Most of these activities can be easily detected and monitored, but some, such as oil spills, are unpredictable. 
Many studies in sandy beach communities assign to natural oscillations in the abundance of numerically dominant populations as the cause of temporal variation of macrofauna (Holland \& Polgar, 1976; Dexter, 1984; Souza \& Gianuca, 1995; Veloso et al., 1997). In temperate regions, the community composition is strongly influenced by temperature (Whitlatch, 1977; Leber, 1982), which is directly related to food limitation. Seasonality in tropical areas is generally related to rain periods (Dexter, 1979) and to disturb instead of temperature changes. Macrofauna is directly influenced by changes in the sediment constitution (McLachlan, 1996) and in salinity (Ansell et al., 1972; Ansari et al., 1986, Defeo \& de Alava, 1995), beach erosion (Ansell et al., 1972, Ong \& Krishnan, 1995), organic enrichment (Beukema, 1991; Tsutsumi et al., 1991), and fisher activity (Defeo \& de Alava, 1995).

Studies on sandy substrates constituted by rock fragments as well as knowledge of the factors that organize their communities are lacking. The presence of rock fragments enhances environmental heterogeneity and creates moist and shady microhabitats (pers. obs.). According to Woodin (1981), the patterns of distribution and abundance of macrofauna are frequently correlated with environmental heterogeneity, i. e., presence and abundance of physical and/or biogenic structure. These rock fragments can also protect the organisms against desiccation, predation, and water movements, and, in association with sand, enable the settlement and recruitment of both sandy beach and rocky shore organisms (Denadai \& Amaral, 1999).

Furthermore, in some intertidal rocky shores inundated by sand, the structural change in the substrate may cause an increase in the faunal diversity because of the higher environmental heterogeneity (McQuaid \& Dower, 1990). On the other hand, the exclusion of psammophobic species (not tolerant to sand) may cause a reduction in the richness and abundance (Brown et al.,1991).

In this study we describe the annual variation in the molluscan communities, and the factors which influence it, of two structurally similar intertidal environments constituted by sand and rock fragments (São Francisco and Engenho d'Água Beaches).

\section{Materials and methods}

This study was conducted in two intertidal environments constituted by sand and rock fragments, São Francisco and Engenho d'Água, located in the São Sebastião Channel, northern coast of São Paulo State, Brazil. Random samples were taken monthly between August 1995 and July 1996, during low spring tides, totaling $19.08 \mathrm{~m}^{2}$. The temperature (air and sediment), salinity of interstitial water, sediment grain size and calcium carbonate and organic matter contents were also evaluated. Refer to Denadai \& Amaral (1999) for detailed description of the study area and sampling procedure. The molluscan individuals were identified to the lowest taxonomic level possible using the current literature that includes Brazilian species (Warmke \& Abbott, 1975; Abbott \& Dance, 1991; Rios, 1994).

Two-way analysis of variance (ANOVA) was used to compare the environmental variables among the sites and months, followed by Scheffe's test (Zar, 1984). All tests were performed at the 0.05 significance level. Ordination analysis (Reciprocal Averaging) was used to interpret the temporal distribution. This analysis was performed using Hill's method (Hill, 1979), giving equal weight to the species, considering outliers, and standardizing the data by square-root transformation. Diversity $\left(\mathrm{H}^{\prime}\right)$ was calculated using the Shannon-Wiener index in $\log _{2}$ (Krebs, 1989). Student's t-test was used to compare the density of molluscs between the present study and that of Salvador (1995), which was performed in the same area and using the same methodology during the period 1992/93.

\section{Results}

The environmental variables differed between the studied sites and among periods (Table 1). In São Francisco, coarse sand grains dominated the sediment, while medium-sized particles were more abundant in Engenho d'Água (Fig. 1). The composition of the sediment at SF and EA was similar only in summer, when finer sand grains were observed in SF. In EA, the sediment composition did not vary during the year. Calcium carbonate content was higher in $\mathrm{SF}$ than in EA, with exception of the spring period (Fig. 1). The organic matter content was higher in the spring in SF, evidencing an organic enrichment in this period (Fig. 1). Significant differences in salinity were recorded in the study period between SF and EA (Table 1). Salinity variation was higher at $S F$ than at EA because of the presence of a waste-water canal in its supralittoral region (Fig. 1). Air temperature varied from $15^{\circ} \mathrm{C}$ in June to $31^{\circ} \mathrm{C}$ in January, and sediment temperature from $15.5^{\circ} \mathrm{C}$ in September to $32^{\circ} \mathrm{C}$ in January. 
Table 1. Two-way ANOVA for the ellects of study area (SF x EA). in São Sebastião Channel, Brazil. and seasons (period August 1995 to July 1996) on sediment grain size, calcium carbonate content. organic matter content, and salinity. (df. degrees of freetom: MS. mean square).

\begin{tabular}{lcccc}
\hline Source of variation & df & MS & $\Gamma$ & $p$ \\
\hline Sediment grain size $(p h y)$ & & & & \\
$\quad$ Area & 1 & 21.657 & 66.152 & $<0.001$ \\
$\quad$ Season & 3 & 1.138 & 3.477 & 0.018 \\
$\quad$ Area* Season & 3 & 0.868 & 2.652 & 0.051 \\
Calcium carbonate content $(\%)$ & & & & \\
$\quad$ Arca & 1 & 1.619 & 20.634 & $<0.001$ \\
Season & 3 & 1.122 & 14.301 & $<0.001$ \\
Area*Season & 3 & 1.248 & 15.905 & $<0.001$ \\
Organic matter content $(\%)$ & & & & \\
Area & 1 & 0.062 & 0.842 & 0.360 \\
Season & 3 & 1.301 & 17.535 & $<0.001$ \\
Area*Season & 3 & 2.176 & 29.331 & $<0.001$ \\
Salinity (\%o) & & & & \\
Area & 1 & 674.123 & 44.254 & $<0.001$ \\
Season & 3 & 213.361 & 14.007 & $<0.001$ \\
Area*Season & 3 & 84.501 & 5.547 & 0.001 \\
\hline
\end{tabular}
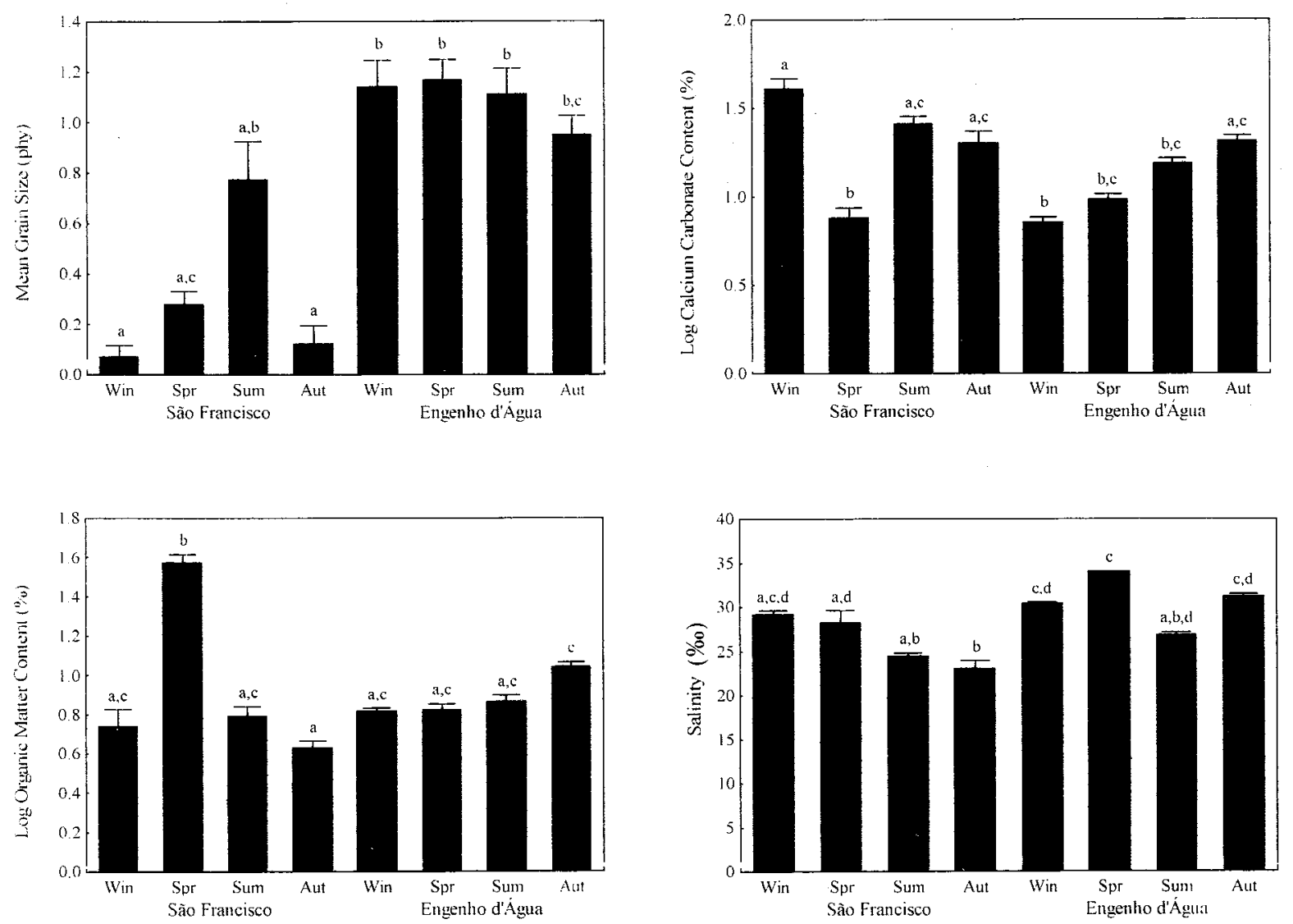

Fig. 1. Comparison of mean values of salinity, sediment grain size. calcium carbonate and organic matter contents between the two studied areas in São Sebastião Chamnel, Brazil and among the seasons (period August 1995 to July 1996). Superscript labels indicate the results of the Sheffer's test for pairwise nultiple comparisons. Similar labels indicate non-significant differences for pair-wise comparisons. (Horizontal bars indicate +1 Standard error). 
A reduction in community richness and abundance occurred in SF after January (Table 2). A total of 22 species and 367 individuals were recorded in the first half of the studied period (August to December/95) compared to 9 species and 188 individuals collected from January to July/96 (Table 2). Correspondence analysis organized the species in two distinct groups: one with species that occurred only in the first period (Tegula viridula, Cerithium atratum, Semele proficua and Corbula cubaniana), and another with species that were found over the entire year (Codakia orbiculata, Lucina pectinata, Tellina lineata and Anomalocardia brasiliana), but in lower abundance after January (Fig. 2).

Table 2. Occurrence and abundance of molluscs along the year in São Francisco Beach, São Sebastião Channel, Brazil.

\begin{tabular}{|c|c|c|c|c|c|c|c|c|c|c|c|c|c|}
\hline \multirow[b]{2}{*}{ SPECIES } & \multicolumn{5}{|c|}{1995} & \multicolumn{8}{|c|}{1996} \\
\hline & $\mathbf{A}$ & $\mathrm{S}$ & $\mathrm{O}$ & $\mathbf{N}$ & D & $\mathbf{J}$ & $\mathbf{F}$ & $\mathbf{M}$ & A & $\mathbf{M}$ & $\mathbf{J}$ & $\mathbf{J}$ & TOT \\
\hline Tegula viridula (Gmelin, 1791) & 2 & 2 & 7 & 8 & 2 & 2 & & & & & & & 23 \\
\hline Cerithium atratum (Born, 1778) & 2 & 6 & 24 & 19 & 3 & & & & & & & & 54 \\
\hline Bittium varium (Pfeiffer, 1840) & & & 1 & & & & & & & & & 1 & 2 \\
\hline Epitonium sp. & & & & & & & & & & & & 1 & 1 \\
\hline Stramonita haemastoma (Linnaeus, 1767) & & & $\mathbf{I}$ & & & & & & & & & & 1 \\
\hline Nassarius sp. & 2 & & & & 3 & & & & & & & & 5 \\
\hline Nassarius vibex (Say, 1822) & & 1 & 4 & & 1 & & & & & & & & 6 \\
\hline Leucozonia nassa (Gmelin, 1791) & & & 2 & & & & & & & & & & 2 \\
\hline Ischnochiton striolatus (Gray, 1822) & & & - & & 1 & & & & & & & & 1 \\
\hline Arcopsis adamsi (Dall, 1886) & 1 & & 1 & 1 & & & & & & & & & 3 \\
\hline Brachidontes solisianus (Orbigny, 1846) & 1 & & & & & & & & & & & & 1 \\
\hline Codakia orbiculata (Montagu, 1808) & 1 & & 5 & 1 & 4 & & & & 1 & 1 & 1 & & 14 \\
\hline Lucina pectinata (Gmelin, 1791) & & 1 & 1 & 1 & 1 & 1 & 1 & & 2 & & 3 & 1 & 12 \\
\hline Diplodonta punctata (Say, 1822) & & & & 1 & & & & & & 1 & & & 2 \\
\hline Mactra fragilis Gmelin, 1791 & & & & 1 & & & & & & & & & 1 \\
\hline Tellina lineata Turton, 1819 & 2 & 5 & 7 & 1 & 5 & & 1 & 1 & & 1 & 1 & 1 & 25 \\
\hline Semele proficua (Pulteney, 1799) & & 4 & 6 & 7 & 3 & & & & & & & & 20 \\
\hline Tagelus divisus (Lightfoot, 1716) & 1 & 1 & & & & & & & & & & & 2 \\
\hline Chione cancellata (Linnaeus, 1767) & 1 & & & & & 1 & & & & & 1 & & 3 \\
\hline Chione subrostrata (Lamarck, 1818) & & 1 & 2 & 1 & 3 & & & & & & & & 7 \\
\hline Anomalocardia brasiliana (Gmelin, 1791) & 13 & 38 & 20 & 22 & 60 & 23 & 15 & 6 & 6 & 6 & 25 & 14 & 248 \\
\hline Corbula caribaea Orbigny, 1842 & 1 & 2 & & & 2 & & & & & & & & 5 \\
\hline Corbula cubaniana Orbigny, 1853 & 20 & 3 & 7 & 6 & 1 & & & & & & & & 37 \\
\hline TOTAL & 47 & 64 & 88 & 69 & 89 & 27 & 17 & 7 & 9 & 9 & 31 & 18 & 475 \\
\hline
\end{tabular}

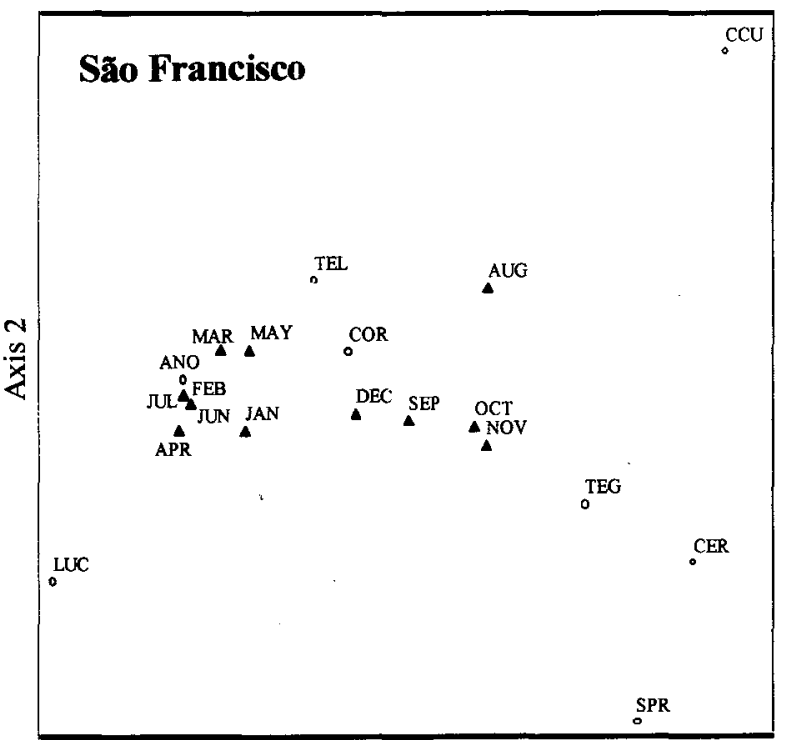

Axis 1

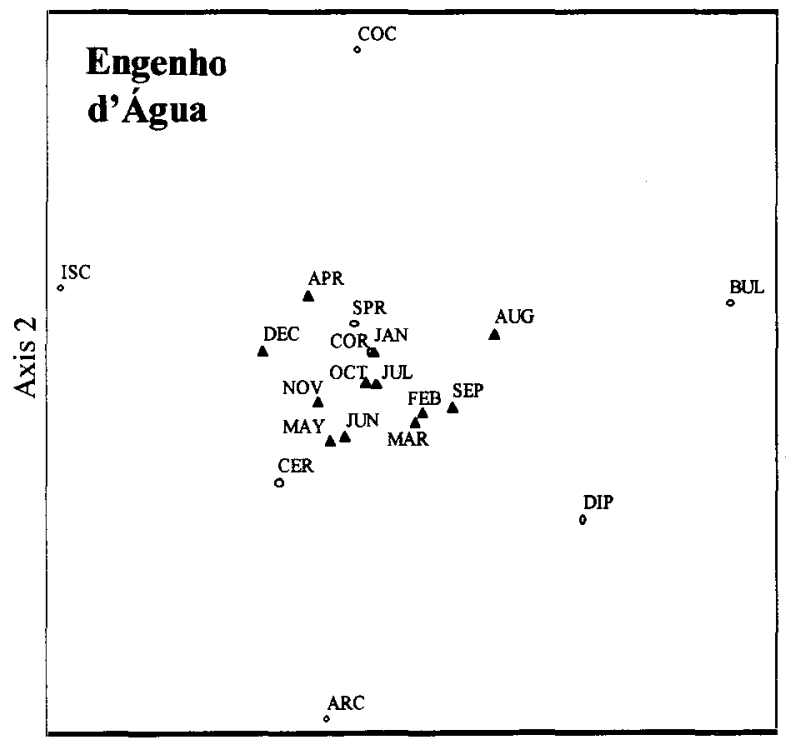

Axis 1

Fig. 2. Correspondence analysis of the most abundant species and of the sample months at São Francisco (total variation explained: axis $1=65.4 \%$, and axis $2=5.0 \%-\mathrm{ANO}=$ Anomalocardia brasiliana, CER= Cerithium atratum, COR= Codakia orbiculata, $\mathrm{CCU}=$ Corbula cubaniana, $\mathrm{LUC}=$ Lucina pectinata, $\mathrm{SPR}=$ Semele proficua, $\mathrm{TEG}=$ Tegula viridula, TEL $=$ Tellina lineata) and at Engenho d'Água (total of variation explained: axis $1=34.3 \%$, and axis $2=$ $2.6 \%-\mathrm{ARC}=$ Arcopsis adamsi, $\mathrm{BUL}=$ Bulla striata, $\mathrm{CER}=$ Cerithium atratum, $\mathrm{COC}=$ Codakia costata, $\mathrm{COR}=$ Codakia orbiculata, $\mathrm{DIP}=$ Diplodonta punctata, $\mathrm{ISC}=$ Ischnochiton striolatus, $\mathrm{SPR}=$ Semele proficua). 
Higher values of richness and abundance were recorded in EA, with only a small reduction from January to May/96 (Table 3). Species were ordered in relation to their presence and abundance in the months (Fig. 2). A major group was formed by species that were frequent during the entire year (Cerithium atratum, Arcopsis adamsi, Codakia costata, C. orbiculata and Semele proficua). Other species as Ischnochiton striolatus (spring - October, November and December), Bulla striata (winter/spring - August, September, and October) and Diplodonta punctata (earlier spring September) showed distinct seasonal distributions. In general, the abundance decreased in the autumn
(March, April), but most of the species remained present.

Figure 3 shows the Shannon diversity index of the sampled months (abscissa) vs. the number of species (ordinate). The fitted line represents the log of the number of species, i.e., the highest diversity value that the community can attain for a given richness. The distance between points and this line is an indirect measure of evenness. Diversity in SF was higher from August to December than at other periods, but evenness was low for all months. In EA, medium to high diversity values was recorded for all sampling periods, but with low values in April. Evenness in EA was high in all periods.

Table 3. Occurrence and abundance of molluscs along the year in Engenho d'Água Beach, São Sebastião Channel, Brazil.

\begin{tabular}{|c|c|c|c|c|c|c|c|c|c|c|c|c|c|}
\hline \multirow[b]{2}{*}{ SPECIES } & \multicolumn{5}{|c|}{1995} & \multicolumn{8}{|c|}{1996} \\
\hline & A & $S$ & $\mathrm{O}$ & $\mathrm{N}$ & $\mathrm{D}$ & $\mathrm{J}$ & $\mathrm{F}$ & $\mathrm{M}$ & A & $\mathbf{M}$ & $\mathrm{J}$ & $\mathrm{J}$ & TOT \\
\hline Fissurella rosea (Gmelin, 1791) & 1 & & & & & & & & & & & & 1 \\
\hline Tegula viridula (Gmelin, 1791) & & & 1 & 3 & 1 & & & 1 & & & & 1 & 7 \\
\hline Astraea phoebia Röding, 1798 & & & 1 & & & & & & & & & & 1 \\
\hline Neritina virginea (Linnaeus, 1758) & & 2 & & & & & & & & & & & 2 \\
\hline Phenacolepas hamillei (Fischer, 1857) & 1 & & & & 1 & & 1 & & & & & 1 & 4 \\
\hline Modulus modulus (Linnaaeus, 1758) & & & & & & & 1 & 1 & & 1 & & & 3 \\
\hline Cerithium atratum (Bom, 1778) & 1 & 6 & 6 & 8 & 9 & 3 & 3 & 1 & 1 & 6 & 17 & 26 & 87 \\
\hline Natica pusilla Say, 1822 & & & & & & & & & & & & 1 & 1 \\
\hline Chicoreus (Siratus) senegalensis Gmelin, 1791 & & 1 & & & & & & & & & & & 1 \\
\hline Trachypolia nodulosa (C.B.Adams, 1845) & 1 & & 3 & & & & 1 & 1 & & 1 & 1 & 4 & 12 \\
\hline Pisania pusio (Linnaeus, 1758) & & & & 1 & & & & & & & & 2 & 3 \\
\hline Nassarius $\mathrm{sp}$ & 1 & & & & & & & & & & & & 1 \\
\hline Leucozonia nassa (Gmelin, 1791) & & & & & 2 & & 1 & 1 & & & & & 4 \\
\hline Olivella minuta (Link, 1807) & 1 & & & & & & & & & & & & 1 \\
\hline Bulla striata Bruguière, 1792 & 20 & 7 & 10 & & & 2 & 12 & 1 & & & 2 & 5 & 59 \\
\hline Ischnochiton striolatus (Gray, 1828) & & & 12 & 7 & 15 & 3 & 1 & & 1 & 2 & 4 & 2 & 47 \\
\hline Nucula semiornata Orbigny, 1846 & & & & 1 & & & & & & & & & 1 \\
\hline Arcopsis adamsi (Dall, 1886) & & 2 & 10 & 12 & 1 & 1 & 11 & 4 & & 3 & 7 & 2 & 53 \\
\hline Lioberus castaneus (Say, 1822) & & & & & & & & & & 1 & & & 1 \\
\hline Limaria pelucida (C.B.Adams, 1846) & & & 1 & & & & & & & & & & 1 \\
\hline Codakia costata (Orbigny, 1842) & 2 & 1 & 3 & 4 & 2 & 4 & 1 & 1 & 2 & & & 3 & 23 \\
\hline Codakia orbiculata (Montagu, 1808) & 10 & 5 & 11 & 9 & 6 & 9 & 11 & 5 & 5 & 8 & 11 & 15 & 105 \\
\hline Diplodonta punctata (Say, 1822) & 4 & 9 & 2 & 2 & & 3 & 4 & 2 & & 2 & 1 & 3 & 32 \\
\hline Laevicardium brasilianum (Lamarck, 1819) & & & & & & 1 & & & & & & & 1 \\
\hline Mactra fragilis Gmelin, 1791 & & & & 1 & & & & & & & & & 1 \\
\hline Solen tehuelchus Orbigny, 1843 & & & 1 & & & & & & 1 & 1 & & & 3 \\
\hline Tellina lineata Turton, 1819 & 1 & 2 & 2 & & & 1 & & & 1 & 3 & 1 & 1 & 12 \\
\hline Tellina versicolor De Kay, 1843 & & & & 2 & & & & & & & & & 2 \\
\hline Semele proficua (Pulteney, 1799) & 9 & 6 & 16 & 20 & 10 & 9 & 11 & 2 & 2 & 4 & 5 & 11 & 105 \\
\hline Semele purpurascens (Gmelin, 1791) & & & & 1 & & & 1 & & & 2 & 1 & 1 & 6 \\
\hline Ervilia nitens (Montagu, 1806) & 1 & & & & & & & 3 & & 1 & & 10 & 15 \\
\hline Tagelus divisus (Spengler, 1794) & 3 & & I & & & & & & & 1 & 1 & & 6 \\
\hline Ventricolaria rigida (Dillwyn, 1817) & & 1 & & & & 1 & & & & & & & 2 \\
\hline Anomalocardia brasiliana (Gmelin, 1791) & & & & & & & & 1 & & & 1 & & 2 \\
\hline Gouldia cerina (B.B.Adams, 1845) & 2 & 1 & 1 & 1 & 4 & & & 1 & & & & & 10 \\
\hline Dosinia concentrica (Born, 1778) & 1 & & & & & & & & & & & & 1 \\
\hline Corbula caribaea Orbigny, 1843 & & & 1 & 1 & & & 1 & & 1 & 1 & & & 5 \\
\hline Corbula cubaniana Orbigny, 1853 & & & 1 & 3 & 2 & 1 & & & & & & & 7 \\
\hline TOTAL & 59 & 43 & 83 & 76 & 53 & 38 & 60 & 25 & 14 & 37 & 52 & 88 & 628 \\
\hline
\end{tabular}



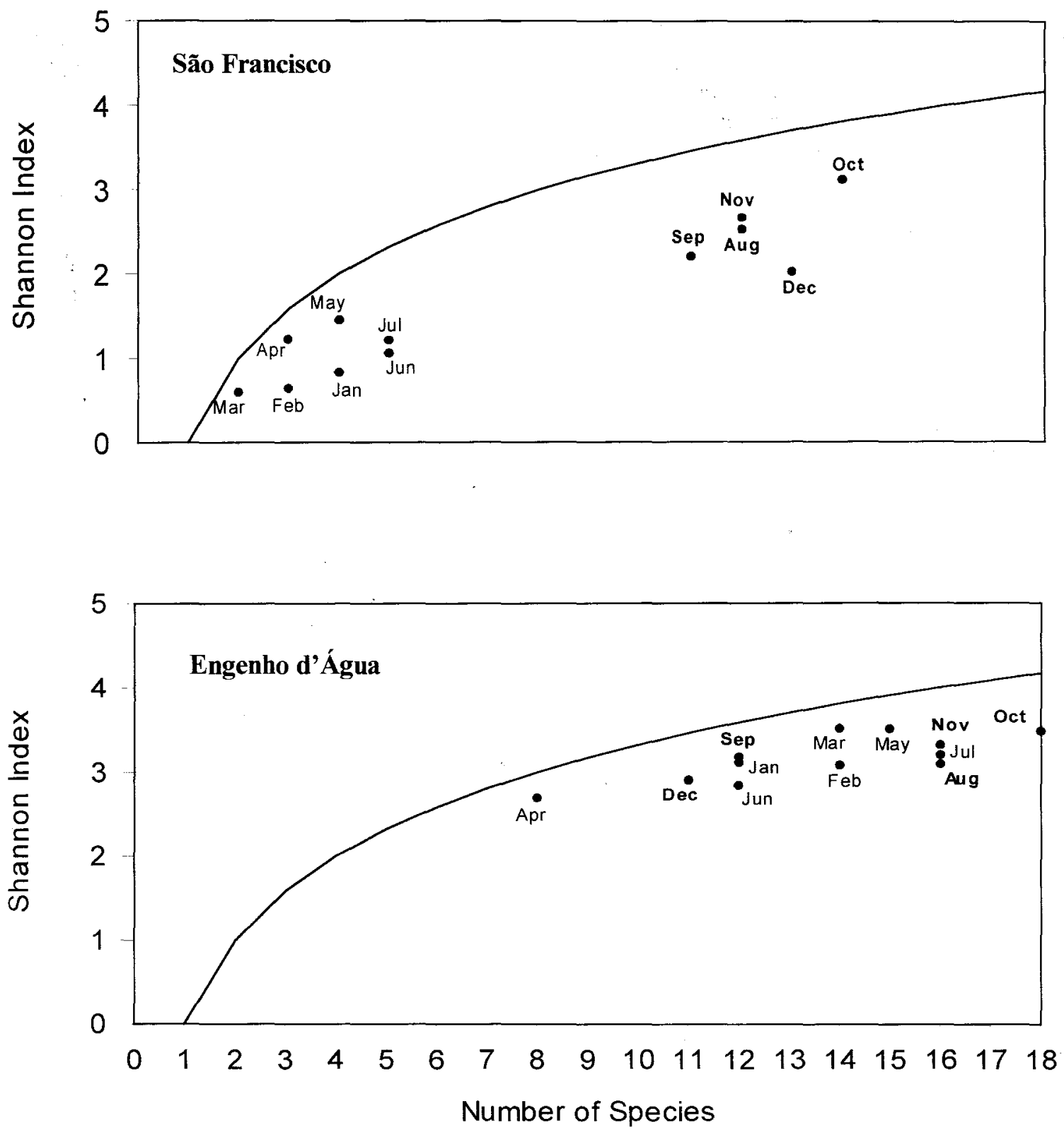

Fig. 3. Relationships between diversity (Shannon Index) and richness at the sample months in São Francisco and Engenho d'Água. evidencing the $\log _{2}$ (evenness) curve.

A comparison between the present investigation and a previous study in EA (Salvador, 1995) revealed some differences in environmental variables and community composition (Table 4 ). The mean diameter of sand particles tended to decrease from the previous to the present study $(\mathrm{t}=2.442, \mathrm{df}=5$, $\mathrm{p}=0.059 ; \phi=0.912 \pm 0.094$ and $\phi=1.091 \pm 0.098$, respectively). Organic matter content was higher in the first period $(\% \mathrm{OM}=1.659 \pm 0.096)$ than in the second $\quad(\% \mathrm{OM}=1.342 \pm 0.078 ; \quad \mathrm{t}=-4.655, \quad \mathrm{df}=5$, $\mathrm{p}=0.006$ ). Forty-one species and 238 individuals were collected in the earlier study (1992/93), in comparison to 39 and 628 were recorded in the present study (1995/96). Only 26 species were common to both periods, with evident differences in their abundance. Tegula viridula, Olivella minuta, Codakia costata, Diplodonta punctata, D. semiaspera, Ervilia nitens, and Gouldia cerina were more abundant in the first period, while Cerithium atratum and Codakia orbiculata were more abundant in the second. Bulla striata, Ischnochiton striolatus, Arcopsis adamsi, and Semele proficua showed high densities in both studies. 
Table 4. Absolute abundance $(\mathrm{N})$ and Density $/ \mathrm{m}^{2}$ of molluscs in Engenho D'Água Beach, São Sebastião Channel, Brazil in the periods 92/93 (Salvador, 1995) and 95/96 (Denadai \& Amaral, 1999; Present study).

\begin{tabular}{|c|c|c|c|c|c|c|c|c|c|}
\hline \multirow[b]{2}{*}{ SPECIES } & \multicolumn{2}{|c|}{ 1992/93 } & \multicolumn{2}{|c|}{$1995 / 96$} & \multirow[b]{2}{*}{ SPECIES } & \multicolumn{2}{|c|}{$1992 / 93$} & \multicolumn{2}{|c|}{$1995 / 96$} \\
\hline & $\mathrm{N}$ & Dens. & $\mathrm{N}$ & Dens. & & $\mathrm{N}$ & Dens. & $\mathrm{N}$ & Dens. \\
\hline Fissurela rosea & & & 1 & 0.06 & Diplodonta punctata & 21 & 13.04 & 32 & 5.45 \\
\hline Tegula viridula & 5 & 3.23 & 7 & 0.90 & Diplodonta semiaspera & 7 & 4.79 & 1 & 0.55 \\
\hline Astraea phoebia & & & 1 & 0.55 & Trachycardium muricatum & 1 & 0.11 & & \\
\hline Neritina virginea & & & 2 & 0.11 & Laevicardium brasilianum & 1 & 0.11 & 1 & 0.06 \\
\hline Phenacolepas hamillei & 1 & 0.11 & 4 & 0.73 & Mactra fragilis & 1 & 0.11 & 1 & 0.06 \\
\hline Modulus modulus & 1 & 0.11 & 3 & 0.17 & Solen tehuelchus & 2 & 0.22 & 3 & 0.67 \\
\hline Cerithium atratum & 5 & 5.91 & 86 & 16.48 & Tellina sp. & 1 & 0.11 & & \\
\hline Polinices lacteus & 1 & 0.11 & & & Tellina lineata & & & 12 & 0.69 \\
\hline Natica pusilla & & & I & 0.55 & Tellina versicolor & 5 & 0.55 & 2 & 0.11 \\
\hline Chicoreus senegalensis & & & 1 & 0.06 & Macoma cleryana & 1 & 1.45 & & \\
\hline Trachypolia nodulosa & 5 & 1.89 & 12 & 1.69 & Semele proficua & 29 & 19.28 & 105 & 15.09 \\
\hline Stramonita haemastoma & 1 & 0.11 & & & Semele purpurascens & 2 & 0.22 & 6 & 0.84 \\
\hline Pisania pusio & & & 3 & 0.17 & Ervilia nitens & 8 & 8.92 & 15 & 0.86 \\
\hline Nassarius sp. & & & 1 & 0.06 & Tagelus divisus & 2 & 0.22 & 6 & 1.40 \\
\hline Nassarius vibex & 3 & 0.33 & & & Ventricolaria rigida & & & 2 & 0.06 \\
\hline Leucozonia nassa & 3 & 1.67 & 4 & 0.23 & Chione subrostrata & 5 & 1.89 & & \\
\hline Olivella minuta & 5 & 4.57 & 1 & 0.06 & Chione intapurpurea & 1 & 1.45 & & \\
\hline Bulla striata & 14 & 9.58 & 59 & 9.88 & Anomalocardia brasiliana & 2 & 0.22 & 2 & 0.61 \\
\hline Ischnochiton striolatus & 19 & 8.80 & 47 & 6.76 & Transennella stimpsoni & 1 & 1.45 & & \\
\hline Nucula semiornata & & & 1 & 0.06 & Gouldia cerina & 35 & 14.59 & 10 & 1.57 \\
\hline Lunarca ovalis & 1 & 0.11 & & & Pitar fulminatus & 7 & 2.11 & & \\
\hline Arcopsis adamsi & 13 & 5.46 & 53 & 8.04 & Pitar palmeri & 1 & 0.11 & & \\
\hline Lioberus castaneus & 3 & 1.67 & 1 & 0.55 & Dosinia concentrica & & & 1 & 0.06 \\
\hline Limaria pelucida & & & 1 & 0.06 & Corbula caribaea & 4 & 1.78 & 5 & 0.79 \\
\hline Codakia costata & 13 & 5.46 & 23 & 2.33 & Corbula cubaniana & 1 & 1.45 & 7 & 2.39 \\
\hline Codakia orbiculata & 5 & 1.89 & 105 & 15.65 & Thracia similis & 1 & 0.11 & & \\
\hline Divaricella quadrisulcata & 1 & 1.45 & & & & & & & \\
\hline & & & & & TOTAL & 238 & 126.81 & 628 & 96.47 \\
\hline
\end{tabular}

\section{Discussion}

The substrate constitution of the studied sites, with sand and rock fragments, create an heterogeneous environment that support both sandy beach and rocky shore species (Denadai \& Amaral, 1999), leading to higher diversities in comparison to typical sandy beaches (Bally, 1983; Dexter, 1984; Defeo et al. 1992; Veloso et al., 1997). McQuaid \& Dower (1990) observed an increase in the fauna richness when rocky substrates were inundated by sand, through increasing the environmental heterogeneity. These authors classified the intertidal organisms in a spectrum of sand tolerance as: (1) psammophobic, restricted to rocky substrates free of sand; (2) sand-tolerant, occurring in both inundated and sand free rocky areas; (3) sand-dependent, found only in association with sand, and (4) psammophilic, restricted to sand column.

In December (summer) a reduction in environmental heterogeneity was evident given the rock fragments of SF were covered by sand due to sea storms common to this period. An accentuated decrease in the mollusc fauna richness and abundance was observed after this disturb, with the exclusion of species associated with rocks (Denadai \& Amaral, 1999), mainly gastropods and some bivalves ( $A$. adamsi, Corbula caribaea and $C$. cubaniana). In fact, storms and monsoons are known to play an important role in community structure by eroding sandy beaches (Ansell et al., 1972; Ong \& Krishnan, 1995). McLachlan (1996) observed changes in the macrofaunal composition (abundance and species exclusion) in a sandy beach after coarse sand addition originating from diamond mines in Namibia, thus reinforcing the importance of sediment constitution to sandy beach macrofaunal structure (Dexter, 1984; McLachlan, 1990).

Organic enrichment influences the community composition, reducing the diversity by exclusion of low tolerant especies and increasing the biomass associated with the dominance of a few opportunistic species (Pearson \& Rosenberg, 1978; Warwick, 1986, 1988). There are two waste-water canals in the supralittoral region of São Francisco that are responsible by an increase in the coliform bacteria in the summer period (Denadai et al., in 
press). In fact, the dominance of the polychaetes Capitella capitata, Scolelepis squamata, and Laeonereias acuta, and of the tubificid oligochaetes, species largely known as indicators of organic pollution (Grassle \& Grassle, 1974; Pearson \& Rosenberg, 1978; Amaral et al., 1998), in the same period in SF (Rizzo \& Amaral, 2000) evidence the organic pollution. Despite the clam Anomalocardia brasiliana, the dominant species in São Francisco (Denadai \& Amaral, 1999), is common in organically-enriched areas (Schaeffer-Novelli, 1980), it also decreased in density after summer as the other ones. This species showed a tendency to increase in abundance after June, the start of its recruitment period (Salvador, 2001), indicating a successional event. Organic pollution showed to be a relevant factor in structuring the studied communities (Denadai et al., in press), as in other marine environments. Despite the significant variation in the contents of calcium carbonate during the year in both sites, this environmental variable did not show any clear relationship with the temporal variation of the molluscs.

Temporal oscillations in communities not subject to disturbances, such as Engenho d'Água, are probably a consequence of the reproductive cycles of the dominant species, as suggested by several authors (Holland \& Polgar, 1976; Dexter, 1984; Souza \& Giannuca, 1995; Veloso et al., 1997). Studies on the molluscan population dynamics in São Sebastião Channel have been made with the bivalves Anomalocardia brasiliana and Corbula cubaniana (Salvador, 2001) and the gastropod Cerithium atratum (Denadai, 2001). According Salvador (2001), Anomalocardia brasiliana presents new recruits from early winter to early summer (June to November) and Corbula cubaniana along winter, spring and summer (July to February). Cerithium atratum also presents a large recruitment period, between April and October, with the peak in June (earlier winter). The species that were common to both SF and EA sites (Cerithium atratum, Codakia orbiculata and Semele proficua) did not present the same temporal pattern, occurring only in the earlier period in SF and along all the year in EA. These differences although can be attributed to specific causes in each site, i.e., disturbs in SF and recruitment patterns in EA.

Natural marine communities are continualiy changing as showed by the comparison of the faunistic composition in Engenho d'Água Beach between the periods of 95/96 (present study) and 92/93 (Salvador, 1995). Such changes are generally explained by environmental modifications (Ansell et al., 1972; Whitlatch, 1977; Dexter, 1979; McLachlan, 1996), but they may be a consequence of the non-stable relationships among the populations that constitute the community (Dexter, 1984; Veloso et al., 1997). Engenho d Água is a visually dynamic intertidal area given the degree of exposure of the stones as well as the algae coverage, are constantly changing. A significant alteration in the sediment constitution was evidenced by a reduction in the mean grain size and organic matter content. The fauna also showed a marked variation between these two periods. Fifteen species disappeared while thirteen species were recorded for the first time. Twenty-six species were common to both periods but with a great variation in their abundances. Despite the absence of information on how the sediment grain size and organic matter influence such species, a relationship may be stablished between environmental and faunistic variation in EA.

Structural changes, such as the coverage of the rock fragments by sand, play a major role controlling the fauna distribution, contrasting to the marked influence of the hydrodynamics and sediment constitution in typical sandy beaches. The high community diversity in such habitats is associated with the presence of moist and shady microhabitats and by the presence of both rocky shore and sandy beach organisms.

\section{Acknowledgments}

This study was supported by grants from the Conselho Nacional de Desenvolvimento Científico e Tecnológico (CNPq) and from the Fundo de Apoio à Pesquisa (FAEP - UNICAMP). We wish to express our thanks to E. S. Marinho, A. M. Rosa (UNICAMP), and the technicians of the Centro de Biologia Marinha of the Universidade de São Paulo (CEBIMar-USP) who helped in the fieldwork. We are particularly grateful to CEBIMar for logistical support, Dr. C. A. L. Freire (IMECC - UNICAMP) for help in diversity analysis, and Dr. J. W. Reid for revision in the English text. We are grateful also to the three anonymous reviewers for their criticism and suggestions.

\section{References}

Abbott, R. T. \& Dance, S. P. 1991. Compendium of seashells. London, Charles Letts e Co. Ltd. $411 \mathrm{p}$.

Amaral, A. C. Z.; Morgado, E. H. \& Salvador, L. B. 1998. Poliquetas bioindicadores de poluição orgânica em praias paulistas. Rev. Bras. Biol., 58(2):307-316. 
Ansari, Z. A.; Ingole, B. S.; Banerjee, G. \& Parulekar, A. H. 1986. Spatial \& temporal changes in benthic macrofauna from Mandovi \& Zuari Estuaries of Goa, West Coast of India. Indian J. mar. Sci., 15(4):223-229.

Ansell, A. D.; Sivadas, P.; Narayanan, B.; Sankaranarayanan, V. N. \& Trevallion, A. 1972. The ecology of two sandy beaches in South West India. I. Seasonal changes in physical and chemical factors, and in macrofauna. Mar. Biol., 17(1):38-62.

Bally, R. 1983. Intertidal zonation on sandy beaches of the west coast of South Africa. Cah. Biol. mar., 24(1):85-103.

Beukema, J. J. 1991. Changes in composition of bottom fauna of a tidal-flat area during a period of eutrophication. Mar. Biol., 111(2):293-301.

Brown, A. C.; Wynberg, F. R. P. \& Harris, S. A. 1991. Ecology of shores of mixed rock and sand in False Bay. Trans. R. Soc. S. Afr., 47(45):563-573.

Defeo, O. \& de Alava, A. 1995. Effects of human activities on long-term trends in sandy beach populations: the wedge clam Donax hanleyanus in Uruguay. Mar. Ecol. Progr. Ser., 123(13):73-82.

Defeo, O.; Jaramillo, E. \& Lyonnet, A. 1992. Community structure and intertidal zonation of the macroinfauna on the Atlantic coast of Uruguay. J. coast. Res., 8(4):830-839.

Denadai, M. R. 2001. Moluscos de praias do litoral norte do Estado de São Paulo: Comunidades de ambientes entremarés de baixo hidrodinamismo; Biologia populacional e produção secundária de Cerithium atratum (Born, 1778). Tese de doutorado. Rio Claro, UNESP, Instituto de Biociências. 89 p.

Denadai, M. R. \& Amaral, A. C. Z. 1999. A comparative study of intertidal molluscan communities in sandy beaches, São Sebastião Channel, São Paulo State, Brazil. Bull. mar. Sci., 65: 91-103.

Denadai, M. R.; Amaral, A. C. Z.; Turra, A. (in press). Spatial distribution of molluscs on sandy intertidal substrates with rock fragments in southeastern Brazil. Estuar. coast. Shelf Sci.
Dexter, D. M. 1979. Community structure and seasonal variation in intertidal Panamaian Sandy Beaches. Estuar. coast. mar. Sci., $9(5): 543-558$.

Dexter, D. M. 1984. Temporal and spatial variability in the community structure of the fauna of four sandy beaches in south-eastern New South Wales. Austr. J. mar. Freshwat. Res., 35(6):663-672.

Grassle, J. F. \& Grassle, J. P. 1974. Opportunistic life histories and genetic systems in marine benthic polychaetes. J. mar. Res., 32(2):253284.

Hill, M. O. 1979. Twinspan - A Fortran program for arranging multivariate data in a ordered twoway table by classification of the individual and attributes. New York, Cornell University Press.

Holland, A. F. \& Polgar, T. T. 1976. Seasonal changes in the structure of an intertidal community. Mar. Biol., 37(4):341-348.

Krebs, C. J. 1989. Ecological methodology. New York, Harper \& Row. 654p.

Leber, K. M. 1982. Seasonality of macroinvertebrates on a temperate, high wave energy sandy beach. Bull. mar. Sci., 32(1):86-98.

McLachlan, A. 1990. Dissipative beaches and macrofauna communities on exposed intertidal sands. J. coast. Res., 6(1):57-71.

McLachlan, A. 1996. Physical factors in benthic ecology: effects of changing sand particle size on beach fauna. Mar. Ecol. Progr. Ser., 131(13):205-217.

McQuaid, C. D. \& Dower, K. M. 1990. Enhancement of habitat heterogeneity and species richness on rocky shores inundated by sand. Oecologia, 84(1):142-144.

Ong, B. \& Krishnan, S. 1995. Changes in the macrobenthos community of a sand flat after erosion. Estuar. coast. Shelf Sci., 40(1):21-33.

Pearson, T. H. \& Rosenberg, R. 1978. Macrobenthic succesion in relation to organic enrichment and pollution of the marine environment. Oceanogr. mar. Biol. a. Rev., 16: 229-311. 
Rios, E. C. 1994. Seashells of Brazil. $2^{\text {a }}$ ed. Rio Grande, Editora da FURG. 492 p.

Rizzo, A. E. \& Amaral, A. C. Z. 2000. Temporal variation of annelids in the intertidal zone of beaches of the São Sebastião Channel, southern Brazil. J. mar. biol. Ass. U. K., 80(6):10071017.

Salvador, L. B. 1995. Distribuição espaço-temporal das populações de moluscos da região entremarés de praias da Ilha de São Sebastião (SP). Dissertação de mestrado. Rio Claro, UNESP, Instituto de Biociências. 139 p.

Salvador, L. B. 2001. Malacofauna da região entremarés de praias de areia com fragmentos de rocha: Distribuição temporal e espacial; Dinâmica populacional e produção secundária de Anomalocardia brasiliana (Gmelin, 1791) e Corbula cubaniana Orbigny, 1853. Tese de doutorado. Rio Claro, UNESP, Instituto de Biociências. $73 \mathrm{p}$.

Schaeffer-Novelli, Y. 1980. Análise populacional de Anomalocardia brasiliana (Gmelin, 1791) na Praia do Saco da Ribeira, Ubatuba, Estado de São Paulo. Bolm Inst. oceanogr., S Paulo, 29(2):351-355.

Souza, J. R. B. \& Gianuca, N. M. 1995. Zonation and seasonal variation of the intertidal macrofauna on a sandy beach of Paraná State, Brazil. Sci. Mar., 59(2):103-111.

Tsutsumi, H.; Kikuchi, T.; Tanaka, M.; Higashi, T.; Imasaka, K. \& Miyazaki, M. 1991. Benthic faunal succession in a cove organically polluted by fish farming. Mar. Pollut. Bull., 23:233-238.
Veloso, V. G.; Cardoso, R. S. \& Fonseca, D. B. 1997. Spatio-temporal characterization of intertidal macrofauna at Prainha Beach (Rio de Janeiro State). Oecol. Brasil., 3:213-225.

Warmke, G. L. \& Abbott, R. T. 1975. Caribbean seashells. New York, Dover publications. 348p.

Warwick, R. M. 1986. A new method for detecting pollution effects on marine macrobenthic communities. Mar. Biol., 92(4):557-562.

Warwick, R. M. 1988. The level of taxonomic discrimination required to detect pollution effects on marine benthic communities. Mar. Pollut. Bull., 19(6):259-268.

Whitlatch, R. B. 1977. Seasonal changes in the community structure of the macrobenthos inhabiting the intertidal sand and mud flats of Barnstable Harbor, Massachusetts. Biol. Bull., 152(2):275-294.

Woodin, S. A. 1981. Disturbance and community structure in a shallow watter sand flat. Ecology, 62(4):1052-1066.

Zar, J. H. 1984. Biostatistical analysis. $2^{\text {nd }}$ ed. Englewood Cliffs, N.J., Prentice-Hall. 718p.

(Manuscript received 13 November 2000; revised 20 March 2001; accepted 06 June 2001) 